\title{
INDEX TO VOLUME I5
}

\section{A}

Acetylene flame, Spectrum of, 639 .

Acid Bessemer steels, oxygen content, 259.

Adler, L., J. R. Cain and, Equilibrium conditions in the system carbon, iron oxide, and hydrogen in relation to the Ledebur method for determining oxygen in steel, 353 .

Air, Combustible gas in, 47 .

Airplane antenna constants, 199.

Alloy steel, Transformations in, $9 r$.

Aluminum amd its light alloys, 105.

Aluminum, Some alloys of, with magnesium and with zinc, 653 .

Analysis, water, Turbidity standard of, 693 .

Annealing and characteristics of glass, 537 .

Antenna and coil aerials in radio transmission and reception, 435 .

Antenna constants, Airplane, 199.

\section{B}

Boiling point of sulphur, $16_{3}$.

Buckingham, E., and J.D. Edwards, Efflux of gases through small orifices, 573 .

Burgess, H. A., E. F. Mueller and, Standardization of the sulphur boiling point, ${ }^{6} 63$.

\section{C}

Cain, J. R., and L. Adler, Equilibrium conditions in the system carbon, iron oxide, and hydrogen in relation to the Ledebur method for determining oxygen in steel, 353 .

- and E. Peltijohn, Oxygen content by the Ledebur method of acid Bessemer steels deoxidized in various ways, 259.

Calcium vapors, electrons in, 723 .

Carbon, iron oxide, and hydrogen, system, equilibrium conditions, 353 .

Characteristics of glass, 537 .

Cheney, W. L., Magnetic testing of straight rods in in intense fields, 625 .

Coblentz, $W . W$., Constants of radiation of a uniformly heated inclosure, 529 .

- Distribution of energy in the spectrum of an acetylene flame, 639 .

- Methods for computing and Intercomparing radiation data, 6 I 7 .

- , and H. Kahler, Reflecting power of stellite and lacquered silver, 215 .

__ - - Some optical and photoelectric properties of molybdenite, 12r.

- - Spectral photoelectric sensitivity of silver sulphide and several other substances, $23 \mathrm{r}$.

- M. B. Long, and H. Kahler, Decrease in ultraviolet and total radiation with usage of quartz mercury vapor lamps, $\boldsymbol{x}$.

$10354^{\circ}-20$
Coblentz, W.W., R.G.Wallenberg and, Preparation and reflective properties of some alloys of aluminum with magnesium and with zinc, 653 .

Computing and intercomparing radiation data, 6 i.

Concerning the annealing and characteristics of glass, 537 .

Constants, Airplane antenna, 199.

Constants of radiation of a uniformly heated inclosure, 529.

Constitution and metallography of aluminum and its light alloys with copper and with magnesium, 105.

Contrast sensibility of the eye, 679 .

Combustible gas in the air, instruments for showing, 47 .

Cork, J. M., Airplane antenna constants, 199.

D

Decrease in ultra-violet and total radiation with usage of quartz mercury vapor lamps, $x$.

Dellinger, $J$. $H$., Principles of radio transmission and reception with antenna and coil aerials, 435.

Deoxidized acid Bessemer steels, oxygen content, 259.

Dependence of the input impedance of a three electrode vacuum tube upon the load in the plate circuit, 367 .

Derivatives of physical quantities, 2 r.

Determination of the output characteristics of electron tube generators, 497 .

Determination of thermal expansion of molybdenum, 3 r.

Dilatometer, a new interferential, 669.

Direction of propagation of long electromagnetic waves, $4 \mathrm{I} 9$.

Distribution of energy in the spectrum of an acetylene flame, 639 .

Dry cells, voltage of, 659 .

Duralumin, Heat treatment of, $27 x$.

$\mathbf{E}$

Edwards, J.D., E. Buckingham and, Efflux of gases through small orifices, 573 .

Effect of rate of temperature change on the trans. formations in an alloy steel, 9 r.

Efflux of gases through small orifices, 573 .

Electromagnetic waves, long, 4 ir.

Electrons in vapors of lead and calcium, 723 .

Electron tube generators, output characteristics, 497.

Energy, Distribution of, in the spectrum of an acetylene flame, 639 .

Equilibrium conditious in the system carbon, iron oxide, and hydrogen in relation to the Ledebur method for determining oxygen in steel, 353 .

Expansion of molybdenum, thermal, $3 \mathrm{r}$.

Expansion, thermal, of insulating materials, 387 .

Eye, Contrast sensibility of, 679 . 


\section{F}

Finkelstein, J. L., R. M. Wilhelm and, A standardized method for the determination of solidification points, especially of naphthalene and paraffin, 185 . Flame, acetylene, spectrum of, 639 .

Flaws in rifle-barrel steel, 219 .

Foote, P. D., F. L. Mohler, and H. F. Stimson, Ionization and resonance potentials for electrons in vapors of lead and calcium, 723 .

Freeman, J. R.,jr., P.D. Merica, R. G. Waltenberg and, Constitution and metallography of aluminum and its light alloys with copper and with magnesium, 105.

- - H. Scott and, Use of a modified Rosenhain furnace for thermal analysis, 317 .

\section{G}

Gases, Efflux through small orifices, 573 .

Generators, electron tube, output characteristics of, 497 .

Glass, annealing and characteristics of, 537 .

Gibson, K.S., Photoelectric spectrophotometry by the null method, 325 .

\section{H}

Heat treatment of duralumin, 27 .

Hersey, $M$. D., A relation connecting the derivatives of physical quantities, 2 I.

Hidnert, P., L. W. Schad and, Preliminary determination of the thermal expansion of molybdenum, $3 \mathrm{I}$.

- W. H. Sonder and, Thermal expansion of insulating materials, 387 .

Holler, H.D., and L. M. Ritchie, Relation of voltage of dry cells to hydrogen-ion concentration, 659.

Hull, L. M., Determination of the output characteristics of electron tube generators, 497 .

Hydrogen-ion concentration, Relation to voltage of dry cells, 659 .

\section{I}

Inclosure, Constants of radiation in, 529 .

Input impedance of a three-electrode vacuum tube, 367.

Instruments for showing the presence and amount of combustible gas in the air, 47 .

Insulating materials, Thermal expansion of, 387 .

Intense fields, Magnetic testing of straight rods in, 625 .

Interferential dilatometer, 669.

Inverse-rate method for thermal analysis, ror.

Ionization and resonance potentials for electrons in vapors of lead and calcium, 723.

Iron and mild stecl, Microstructure, 519.

\section{$\mathrm{K}$}

Kahler, H., W.W. Coblentz and, Reflecting power of stellite and lacquered silver, 2 I5.

- - - Some optical and photoelectric properties of molybdenite, ז2I.

,-- , Spectral photoelectric sensitivity of silver sulphide and several other substances, $23 \mathrm{I}$.

,,$-- M$. B. Long and, Decrease in ultra-violet and total radiation with usage of cuartz mercury vapor lamps, $x$.
Kahler, H., and E. P. T. Tyndall, Contrast sensibility of the eye, 679 .

Kouwenhoven, W. B., R. L. Sanford and, Location of flaws in rifle-barrel steel by magnetic analysis, 219.

Krypton spectrum, wave lengths, $25 \mathrm{I}$.

\section{L}

Lacquered silver, Refiecting power, 215.

Lead and calcium vapors, electrons in, 723 .

Ledebur method, 259,353 .

Light alloys of aluminum, 105 .

Load in the plate circuit, 367 .

Location of flaws in rifle-barrel steel by magnetic analysis, 2 Ig.

Long electromagnetic waves, $4 \mathrm{I} 9$.

Long, M. B., W.W. Coblentz, and H. Kahler, Decrease in ultraviolet and total radiation with usage of quartz mercury vapor lamps, I.

\section{M}

Magnetic analysis to locate flaws in rifle-barrel steel, 2 19.

Magnetic testing of straight rods in intense fields, 625 .

Measurements of wave lengths in the spectra of krypton and xenon, 251.

Merica, $P$. $D$., A simplification of the inverse-rate method for thermal analysis, ror.

- - R. G. Waltenberg, and J. R. Freeman, jr., Constitution and metallography of aluminum and its light alloys with copper and with magnesium, ro5.

$\longrightarrow,-$, and H.Scott, Heat treatment of duralu$\min , 27 \mathrm{x}$.

Mcrill, $P . W$., Measurements of wave lengths in the spectra of krypton and xenon, 251.

Metallography of aluminum and its light alloys, I05.

Methods for computing and intercomparing radiation data, $61_{7}$.

Michelson, A. A., Optical conditions accompanying the striae which appear as imperfections in optical giass, $4 \mathrm{I}$.

Microstructure of iron and mild steel at high temperatures, $5 \mathrm{r} 9$.

Mild steel, microstructure, 5 r 9 .

Miller, $J . M$., Dependence of the input impedance of a three-electrode vacuum tube upon the load in the plate circuit, 367 .

Mohler, F. L., P. D. Foote, and H. F. Stimson, Ionization and resonance potentials for electrons in vapors of lead and calcium, $i 23$.

Molybdenite, optical and photoelectric properties, I2I.

Molybdenum, thermal expansion of, $3 \mathrm{I}$.

Mueller, B. F., and $H$. A. Burgess, Standardization of the sulphur boiling point, $I 6_{3}$.

\section{$\mathrm{N}$}

Naphthalene and paraffin, solidification points, 185 . New forms of instruments for showing the presence and amount of combustible gas in the air, 47. New interferential dilatometer, 669.

Null method in photoelectric spectrophotometry, 325 . 


\section{o}

Optical and photoelectric properties of molybdenite, $12 \mathrm{r}$.

Optical conditions accompanying the striae which appear as imperfections in optical glass, $4 \mathrm{I}$.

Optical glass, striae in, $4 \mathrm{r}$.

Orifices, small, Efflux of gases through, 573 .

Output characteristics of electron tube generators, 497.

Oxygen content by the Ledebur method of acid Bessemer steels deoxidized in var ous ways, 259. Oxygen in steel by Ledebur method, 353 .

\section{$\mathbf{P}$}

Paraffin and naphthalene, solidification points, 185 . Pettijolin, E., J. R. Cain and, Oxygen content by the Ledebur method of acid Bessemer steels deoxidized in various ways, 259 .

Photoelectric properties of molybdenite, 12I.

Photoelectric spectrophotometry by the null method, 325 .

Physical quantities, derivatives of, $2 \mathrm{I}$.

Plate circuit, load in the, $36 \%$.

Potentials, Ionization and resonance, 723 .

Preliminary determination of the thermal expansion of molybdenum, $3 \mathrm{r}$.

Preparation and reflective properties of some alloys of aluminum with magnesium and with zinc, 653 .

Priest, I. G., A new interferential dilatometer, 669.

Principles of radio transmission and reception with antenna and coil aerials, 435 .

\section{$\mathbf{R}$}

Radiation, Constants of, 529 .

Radiation data, computing and intercomparing, 6r7.

Radiation in quartz lamps, $x$.

Radio transmission and reception, Principles of, 435.

Rawdon, H.S., and H. Scott, Microstructure of iron and mild steel at high temperatures, 5 I9.

Reflecting power of stellite and lacquered silver, 2 I5 $_{5}$.

Reflective properties of some alloys of aluminum, 653.

Relation connecting the derivatives of physical quantities, 2 r.

Relation of voltage of dry cells to hydrogen-ion concentration, 659.

Resonance potentials for electrons, 723 .

Rifle-barrel steel, Location of flaws, 219.

Ritchie, L. M., H. D. Holler and, Relation of voltage of dry cells to hydrogen-ion concentration, 659 .

Rods, straight, in intense fields, 625 .

Rosenhain furnace, modified, for thermal analysis, 317.

\section{$\mathrm{S}$}

Sanford, R. L., and W. B. Kouwenhoven, Location of flaw's in rifle-barrel steel by magnetic analysis, 219.

Schad, L. IV., and P. Hidnert, Preliminary determination of the thermal expansion of molybdenum, 3 r.

Scoll, $H$., Effect of rate of temperature change on the transformations in an alloy steel, $9 r$.

- and J. R. Freeman, jr., Use of a modified Rosenhain furnace for thermal analysis, 3r7.
Scott, H., P.D. Merica, R. G. Waltenberg and, Heat treatment of duralumin, $27 \mathrm{x}$.

- H.S. Rawdon and, Microstructure of iron and mild steel at high temperatures, 519.

Sensibility of the eye, 679.

Siiver sulphide, Spectral photoelectric sensitivity, $23 \mathrm{r}$.

Simplification of the inverse-rate method for thermal anaiysis, $9 \mathrm{I}$.

Solidification points, method for determination of, 135.

Some optical and photoelectric properties of molybdenite, I2I.

Souder, W. H., ana P. Hidnert, Thermal expansion of insulating materials, ${ }_{3} S_{7}$.

Spectral photoelectric sensitivity of silver sulphide and several other substances, 23 I.

Spectra of krypton and xenton, $25 \mathrm{x}$.

Spectrophotometry, Photoelectric, 325.

Spectrum of an acetylene flame, 639 .

Standardization of the boiling point of sulphur, $1 \sigma_{3}$. Standardized method for determination of solidification points, especially of naphthalene and paraffin, I85.

Standard, Turbidity, of water analysis, 693.

Steel, rifle-barrel, Location of flaws, 219.

Stellite and lacquered silver, Reflecting power, 2 I 5 .

Stimson, H. F., F. L. Mohler, and P. D. Foote, Ionization and resonance potentials for electrons in vapors of lead and calcium, 723 .

Striae in optical glass, $4 x$.

Sulphur boiling point, 163 .

System carbon, iron oxide, and hydrogen, Equilibrium conditions, 353 .

\section{$\mathrm{T}$}

Taylor, A. H., Variations in direction of propagation of long electromagnetic waves, $4 \mathrm{I} 9$.

Temperature change, Effect on the transformation in an alloy steel, $9 \mathrm{r}$.

Testing, Mragnetic, of strai ght rods, 625 .

Therrnal analysis, inverse-rate method, ror.

Thermal analysis with modified Rosenhain furnace, $31 \%$.

Thermal expansion of insulating materials, 387 .

Thermal expansion of molybdenum, $3 x$.

Tool, A.Q., and J. Valasek, Concerning the annealing and characteristics of glass, 537.

Transformations in an alloy steel, 91 .

Turbidity standard of water analysis, 693 .

Tyndall, E. P. T., E. Karrer and, Contrast sensibility of the cye, 679 .

\section{U}

Uniformly heated inclosure, Constants of radiation in, 529 .

Use of a modified Rosenhain furnace for thermal analysis, $31 \%$.

\section{V}

Vacuum tube, Input impedance of, 367 .

Valasek, J., A. Q. Tool and, Concerning the anrealing and characteristics of glass, 537.

Vapor lamps, quartz mercury, r.

Vapors of lead and calcium, Electrons in, 723.

Variation in direction of propagation of long electromagnetic waves, $4 \mathrm{I} 9$.

Voltage of dry cells, 659 . 
W

Waltenberg, R. G., and W.W. Coblentz, Preparation and reflective properties of some alloys of aluminum with magnesium and with zinc, 653 .

,- P. D. Merica, and J. R. Freeman, Constitution and metallography of aluminum and its light alloys with copper and with magnesium, ro5.

- - , and H. Scott, Heat treatment of duralu$\min , 271$.

IVater analysis by turbidity standard, 693 .

Wave lengths in the spectra of krypton and xenon, 251 .

Weaver, E. R., and E. E. Weibel, New forms of instruments for showing the presence and amount of combustible gas in the air, 47 .
Weibel, E. E., E. R. Weaver and, New forms of instruments for showing the presence and amount of combustible gas in the air, 47 .

Wells, $P . V$., Turbidity standards of water analvsis, 693 .

Wilhelm, R. M., and J. L. Finkelsiein, A standardized method for the determination of solidification points, especially of naphthalene and paraflin, 185 .

$\mathrm{X}$

Xenon spectrum, wave lengths, 251. 